\title{
HASRAT PENGARANG DALAM NOVEL GENTAYANGAN KARYA IN- TAN PARAMADITHA: KAJIAN PSIKOANALISIS JACQUES LACAN
}

\author{
Laras Puspa Aruma, ${ }^{\mathrm{*}}$, Pujiharto ${ }^{\mathrm{b},{ }^{*}}$ \\ Magister Sastra, Fakultas Ilmu Budaya, Universitas Gadjah Madaa \\ Fakultas Ilmu Budaya, Universitas Gadjah Mada ${ }^{b}$ \\ laras.puspa.a@mail.ugm.ac.id,pujiharto@ugm.ac.id
}

Artikel diterima: 31 Mei 2020

Artikel direvisi: 13 Juli 2020

Artikel disetujui: 28 Agustus 2020

\begin{abstract}
Abstrak
Gentayangan merupakan novel karya Intan Paramaditha yang menggambarkan kehidupan warga negara ketiga yang bepergian dan hidup di negara pertama. Intan Paramaditha merupakan seorang warga negara ketiga yang telah lebih dari satu dekade hidup berpindah tempat di beberapa kota dan negara. Makalah ini meneliti tentang hasrat Intan Paramaditha yang termanifestasikan dalam novel Gentayangan. Untuk menjawab permasalahan tersebut, digunakan teori dan metode psikoanalisis Lacan. Psikoanalisis Lacan membahas hasrat manusia yang diungkapkan melalui bahasa atau penanda melalui mekanisme metafora dan metonimia. Hasil penelitian membuktikan bahwa novel Gentayangan adalah manifestasi hasrat dan kekurangan Intan sebagai pengarang melalui hasrat untuk menjadi (narsistik) dan hasrat untuk memiliki (anaklitik) demi mencapai keutuhan diri. Dalam penelitian ini juga ditemukan bahwa sebagai subjek berhasrat dan berkekurangan, Intan melakukan perlawanan terhadap Yang Simbolik (hukum) melalui novel Gentayangan, dengan demikian dalam teori psikoanalisis Lacan, Intan Paramaditha adalah subjek maskulin yang mengalami pengebirian oleh adanya hukum atas nama ayah (ayah simbolik).
\end{abstract}

\begin{abstract}
The Gentayangan is a novel by Intan Paramaditha that describes the lives of third citizens who travel and live in the first country. Intan Paramaditha is a third country citizen who has lived more than a decade from one city and country. This paper examines the Intan Paramaditha's desire manifested in the novel Gentayangan. To answer these problems, Lacan's theory and method of psychoanalysis were used. Lacan's psychoanalysis addresses human desires expressed through language or markers through the mechanism of metaphor and metonymy. The results of the research prove that the Gentayangan is a manifestation of Intan Paramaditha's desires and shortcomings as a writer through the desire to be (narcissistic) and the desire to have (anaclitic) in order to achieve wholeness. In this study it was also found that as a subject of desire and need, Intan resisted the Symbolic (legal) through the novel Gentayangan, thus in Lacan's psychoanalytic theory, Intan Paramaditha was a masculine subject which was castrated by the law in the name of father (symbolic father).
\end{abstract}

Keywords: author's desire; narcistic desire; anaclitic desire; Intan Paramaditha

\section{Pendahuluan}

Novel Gentayangan menceritakan tentang seorang perempuan ("kau") yang tidak mampu melakukan perjalanan panjang berkeliling dunia. Kemudian sang perempuan bersekutu dengan iblis untuk bisa memenuhi keinginannya melakukan perjalanan panjang tanpa pulang.

Keunikan Intan menyajikan cerita perjalanan "kau" terletak pada caranya memilih 
konsep "pilih sendiri petualanganmu" selain itu caranya mengaitkan kisah perjalanan tokoh "kau" dengan beberapa dongeng, mitos, serta peristiwa sejarah tragedi 1998 dan Partai Komunis Indonesia (PKI). Dalam mengaitkan peristiwa-peristiwa tersebut dengan kisah perjalanan "kau" menimbulkan pertanyaan apakah yang ingin disampaikan Intan kepada pembaca melalui karyanya yang berjudul Gentayangan. Terlebih dalam menuliskan kisah perjalanan "kau" yang berkaitan dengan peristiwa-peristiwa tersebut, Intan banyak menghadirkan diksidiksi yang seolah dikaburkan dalam mengungkapkan maksudnya.

Novel Gentayangan merupakan karya Intan Paramaditha yang berhasil meraih penghargaan sebagai Buku Sastra Prosa Terbaik Tempo 2017 serta telah diterbitkan ke dalam bahasa Inggris dan Jerman. Intan Paramadhita merupakan seorang akademisi perempuan Indonesia yang memiliki dedikasi tinggi terhadap literasi. Selama lebih dari satu dekade ia hidup berpindah di beberapa kota dan negara. Ia menempuh pendidikan masternya dengan beasiswa penuh di University of California, San Diego, pada tahun 2005-2007 kemudian ia mendapat fellowship dari New York University untuk menjalani pendidikan doktoralnya dalam bidang Kajian Sinema dan lulus dengan predikat distinction pada tahun 2014. Saat ini, ia mengajar Kajian Media dan Film di Macquarie University, Sydney (Paramaditha, 2017:1). Intan Paramaditha telah banyak menerbitkan karya sastra dan telah meraih berbagai penghargaan.

Sebagai seseorang yang lebih dari satu dekade hidup berpindah tempat di beberapa kota dan negara, membuat Intan mengalami suatu pengalaman perjalanan yang membuatnya menyerap berbagai wacana sosial. Salah satunya adalah mengenai aturan batas wilayah, peraturan mengenai batas wilayah mengharuskan warga negara ketiga (berkembang) tidak dapat memiliki akses yang sama dengan warga negara pertama (maju). Sebagai pemegang paspor Indonesia misalnya, sebagai warga negara berkembang, tentu tidak bisa memiliki akses yang sama dengan pemilik paspor Belanda. Menurut paspor indeks tahun 2019 Indonesia hanya memiliki akses bebas visa kurang lebih sebanyak 34 negara, sedangkan Belanda memiliki akses bebas visa kunjung kurang lebih ke-110 negara lain. Sebagai pemegang paspor Indonesia tentu saja perbedaan-perbedaan ini dirasakan oleh Intan. Perbedaan akses tersebut tentu menjadi suatu hambatan bagi warga negara ketiga dalam hal ini Intan Paramaditha dalam melakukan perjalanan ke luar negeri, hal tersebut tentu menjadi suatu faktor munculnya rasa kurang (lack) dalam diri, kekurang-kekurangan inilah yang membawa pada hasrat untuk mecapai kesempurnaan.

Karya sastra merupakan bentuk manifestasi hasrat pengarang, hasrat terbentuk karena adanya kekurangan dalam diri. Menulis karya sastra adalah upaya untuk menutupi rasa kurang dalam diri tersebut. Untuk melihat hasrat pengarang dalam karya sastra dapat dilihat melalui pandangan pengarang akan egoego ideal di dalam karyanya (Manik, 2016:74). Dalam teori psikoanalisis, Lacan mengacu pada Freud mengatakan bahwa hasrat merupakan keinginan yang tidak disadari dengan kata lain hasrat tersimpan dalam wilayah tak sadar.

Faruk (2017:197) mengatakan bahwa memahami karya sastra dalam perspektif Lacan adalah usaha untuk menemukan kondisi bawah sadar seseorang yang dipenuhi oleh kekurangan. Hasrat berada dalam wilayah tak- 
sadar, maka untuk dapat menemukan hasrat seseorang yang terdapat dalam wilayah taksadar dibutuhkan analisis melalui bahasa dalam karya sastra melalui metafora dan metonimia.

Hiasa (2016:67) mengatakan hasrat pada dasarnya adalah keinginan akan kepemilikian identitas, di mana identitas tersebut diperoleh melalui proses identifikasi melalui citraan, penanda utama, dan fantasi.

Bahasa dalam pandangan Lacan disebut penanda. Penanda utama berfungsi sebagai pembawa identitas yang mewakili pengarang. Lacan mengatakan dalam teori psikoanalisisnya bahwa subjek muncul dalam rantai penanda (Kolenc, 2017:90). Lacan mengemukakan penanda utama' (master of signifiers) dapat dilihat melalui kata-kata. Cara penanda-penanda itu berfungsi adalah sebagai pembawa identitas (Bracher, 2009:44).

Melalui bahasa (penanda) sang penulis karya sastra mewujudkan diri dan menyampaikan subjektivitas sebagai subjek dalam masyarakat agar meraih hasrat akan keutuhan diri (Rengganis, 2015:46). Intan Paramaditha sebagai subjek (pengarang) adalah subjek yang berkekurangan. Kekurangan-kekurangan tersebut membawanya pada hasrat untuk memperoleh keutuhan identitasnya. Rasa kekurangan dalam diri Intan, secara tidak sadar ia wujudkan melalui tindakannya menulis novel Gentayangan sebagai manifestasi hasratnya. Usaha untuk dapat mengetahui hasrat pengarang dalam karyanya, dibutuhkan analisis melalui bahasa. Psikoanalisis Lacan membahas hasrat manusia melalui bahasa (penanda) dengan mekanisme metafora dan metonimi. Dengan demikian, novel Gentayangan Intan Paramaditha yang memuat hasrat-hasrat pengarang yang tersembunyi perlu dikaji dengan perspektif Lacan.

Penelitian ini difokuskan untuk mengetahui hasrat Intan Paramadhita yang termanifestasikan dalam novel Gentayangan. Melalui analisis pada metafora dan metonimi yang digunakan pada tokoh cerita maka akan diketahui bagaimana Intan Paramadhita memanifestasikan hasratnya dalam sebuah karya sastra. Dari hasil identifikasi tersebut akan diketahui bagaimana hasrat menjadi dan hasrat memiliki pengarang.

Lacan mengaitkan hasrat dengan kebutuhan (need) dan tuntutan (demand). Kebutuhan dipahami sebagai suatu kebutuhan alami manusia sebagai makhluk biologis, sedangkan tuntutan sebagai ucapan. Kebutuhan mungkin untuk dipuaskan, namun tuntutan tidak mungkin dapat dipuaskan. Namun ada relasi antara pemuasan kebutuhan dan tuntutan. Dalam relasi anak-ibu terjadi tuntutan akan cinta sang ibu yang menjamin terpenuhinya kebutuhan sang anak seperti makan dan minum. Namun tuntutan akan cinta tidak mungkin terpuaskan, sehingga kebutuhan sang anak tak terpuaskan. Dalam hal ini terjadi gap antara kebutuhan dan tuntutan, dan di sinilah letak hasrat. Tuntutan berbeda dengan hasrat, tuntutan bersifat penguasaan (want-to-have), sedangkan hasrat bersifat pengakuan, pengenalan atau identifikasi (want-to-be). Hasrat bersifat tak terbatas, hanya kematian yang menjadi batas hasrat (Lukman, 2011:51-53).

Subjek dalam Lacanian adalah subjek yang selalu berkekurangan. Kekurangan eksistensial ini memicu dua jenis hasrat yaitu hasrat menjadi dan hasrat memiliki. Hasrat memiliki (identitas) adalah hasrat memiliki Liyan sebagai cara untuk memuaskan diri. Sedangkan hasrat menjadi adalah hasrat yang memanifes- 
tasikan dirinya untuk mendapat cinta dari yang lain.

Subjek selalu berusaha untuk mencari keutuhan, akan tetapi keutuhan dan kesempurnaan tidak akan pernah tercapai, sebab kesempurnaan dan keutuhan hanya terdapat pada fase the Real. The Real adalah sesuatu di luar bahasa, karena itu mustahil untuk dilambangkan (Watson, 2016:5).

Dalam pemikiran Lacan selain menyebutkan subjeknya sebagai subjek tidak sadar, subjek hasrat, dan juga subjek perkataan, ia juga menyebutkan bahwa subjek Lacanian masih memiliki karakteristik lainnya. Subjek yang menginginkan kebebasan, akan tetapi terhalang oleh adanya hukum atas nama ayah, dalam hal ini subjek mengalami pengebirian. Subjek yang mengalami pengebirian bukan sebatas subjek laki-laki namun juga perempuan sebab pengebirian dalam pemikiran Lacan bukan persoalan seksualitas. Subjek yang mengalami pengebirian akibat hukum atas nama ayah, dan melakukan perlawanan terhadapnya dalam hal ini disebut subjek maskulin (Lukman, 2011:73).

Penelitian ini merupakan penelitian kualitatif dengan menggunakan metode membaca intensif untuk mengumpulkan data pada novel Gentayangan agar diperoleh datadata dalam novel yang akan digunakan sebagai bahan penelitian. Metode analisis yang digunakan dalam penelitian ini adalah metode Psikoanalisis Lacan dengan dua langkah. Pertama identifikasi bahasa sebagai manifestasi hasrat pengarang akan dilakukan dengan 1) mengumpulkan penanda-penanda utama; 2) menganalisis hubungan antar penanda dengan penanda-penanda lain; 3) pemaknaan penanda berdasarkan mekanisme metafora dan metonimi. Setelah diketahui hubungan makna tersembunyi dalam rangkaian penanda-penanda dalam teks novel Gentayangan kemudian akan dilihat hubungan dengan hasrat pengarang.

Kedua identifikasi hasrat untuk mencari hasrat-hasrat tersembunyi dari penandapenanda dalam novel Gentayangan yang sebelumnya telah dianalisis melalui rangkaian penanda secara metafora dan metonimi. Identifikasi hasrat dilakukan dengan langkah, 1) mengidentifikasi hasrat subjek melalui citraan liyan sebagai cermin tokoh Kau; 2) mengidentifikasi rasa kurang (lack) dan kehilangan subjek untuk mengetahui hasrat subjek; 3) analisis objek a sebagai objek yang diinginkan; 4) pengelompokan hasrat menjadi dan hasrat memiliki subjek. Dengan dilakukannya identifikasi-identifikasi hasrat melalui bahasa pengarang maka akan diketahui hasrat pengarang dalam novel Gentayangan.

\section{Penanda Utama sebagai Pembawa Citra Ideal dalam Sudut Pandang Tokoh "Kau"}

Bahasa dalam Lacan disebut penanda, penanda utama berfungsi sebagai pembawa identitas yang mewakili pengarang, sehingga dalam usaha mengetahui identitas subjek, akan dilihat bagaimana penanda utama yang dilekatkan Intan Paramaditha dalam subjek karyanya.

Dalam novel Gentayangan diketahui adanya penanda tertentu yang mencitrakan objek citra ideal. Tokoh kau dihadirkan Intan sebagai seorang anak yang terlahir dari keluarga berpendidikan, ayah dan ibunya adalah alumni dari Universitas Gadjah Mada yang pada saat itu telah bekerja di Jakarta sebagai karyawan swasta. Dalam konsep Lacan perolehan identitas dimulai dari tahap cermin. Keluarga merupakan cermin pertama subjek dalam pengidentifikasian diri. 
"Ayah dan Ibumu bertemu di Jogja, saat mereka bersua sama-sama belajar di Universitas Gadjah Mada. Mereka selalu membanggakan almamater mereka, salah satu kampus bergengsi di Indonesia" (Paramaditha, 2017:13).

Melalui penanda tertentu seperti 'Universitas Gadjah Mada' dan 'Kampus bergengsi', merupakan metafora dari pendidikan tinggi, dalam hal ini diketahui citra ideal tokoh kau adalah seorang perempuan cerdas dan berpendidikan tinggi seperti Ibunya. Hal tersebutlah yang terus ditranformasikan dalam dirinya dengan menjadi juara kelas agar mendapatkan pengakuan dari Liyan.

"Ilusi bahwa kau bukan orang biasa muncul ketika kau menjadi juara kelas di sekolah dasar dan mengikuti lomba Cerdas Cermat tingkat kotamadya. Ayah dan ibumu sangat bangga padamu..." (Paramaditha, 2017:14).

Penanda-penanda dalam kutipan novel Gentayangan Pilih Sendiri Petualangan Sepatu Merahmu seperti "bukan orang biasa", "juara", "cerdas", "bangga", merupakan citraan ideal yang ditransformasikan ke dalam diri subjek sehingga menjadi hasrat akan identitas subjek. Penanda-penanda tersebut umumnya menjadi suatu yang dihasrati orang, terutama jika didapatkan dari kedua orang tua, khususnya ibu. Dengan menginternalisasi penanda-penanda tersebut, subjek merasa mendapatkan keutuhan pada dirinya, yaitu dibanggakan, disayangi, diidolakan, yang merupakan metafora dari kesempurnaan diri. Dalam tahap cermin, masa ini merupakan masa peralihan dari tubuh terfragmentasi pada gambarang totalitas. Pengenalan diri dalam cermin menghasilkan perasaan kesatuan-diri yang narsistik. Lacan menjelaskan pada tahap cermin, ketika si anak melihat gambar dirinya terpantul dalam cermin, ia akan membuat identifikasi imajiner dengan gambar tersebut. Si anak kemudian dengan gembira melihat pantulan dirinya dalam cermin sehingga merasa 'utuh'. Hal inilah yang terjadi pada kau, rasa keutuhan yang didapatkan subjek diperoleh melalui penanda citra ideal seperti "juara kelas", "cerdas", "bangga", dan "bukan orang biasa" yang membawanya pada identitas anak pintar sehingga memberikannya perasaan utuh. Ini merupakan sebuah penemuan kedirian.

Dalam dalam cermin anak masih bergantung pada ibunya mengenai keamanan fisik dan kesejahteraan, akan tetapi keadaan tersebut tidak selamanya bisa diperoleh oleh kau sebab kehadiran Ayah simbolik memisahkan dirinya dari ibunya, Ayah simbolik adalah simbol bagi hukum dan kebudayaan. Hal tersebut dialami tokoh kau ketika ia harus terpisah dari ibunya yang harus pindah ke Yogyakarta bersama ayahnya akibat diberhentikan bekerja saat terjadi 1998 yang mengakibatkan krisis moneter, akan tetapi kau harus tetap berada di Jakarta untuk menyelesaikan pendidikan. Dalam hal ini kau terpisah dari ibunya akibat kehadiran Ayah simbolik dan kondisi tersebut yang menyebabkan subjek mengalami suatu 'kehilangan'.

Akibat dari rasa kehilangan yang dirasakan kau, akhirnya ia mulai mencari identitas baru. Ia menemukan identitas baru melalui teman sekolahnya yang tergabung dalam geng elit. Lacan mengatakan subjek yang mengalami kehilangan terus mencari identitas baru untuk mendapatkan rasa akan kepenuhan.

"Luar negeri adalah kata yang mewah di SMPmu, Cuma anak bos yang mampu ke luar negeri. Beberapa kawanmu yang tergabung dalam sebuah kelompok elit, geng borju, pernah beberapa kali bertamasya ke Singapura. Masa itu masa gila merek; anggota geng borju menggunakan merek yang dianggap 
Poetika : Jurnal Ilmu Sastra

Vol. 8 No. 1, Juli 2020

keren dari ujung rambut hingga ujung kaki-Levi's, Dr. Martens, L.A. Gaer, Baby G, Ocean Pacific- (Paramaditha, 2017:13).

Dalam kutipan tersebut terdapat penanda tertentu seperti 'luar negeri', 'label berbahasa inggris', dll yang merupkan metafora dari negara maju. Terdapat penanda lain seperti 'borju', 'elit', 'anak bos', yang merupakan metafora dari pemilik modal. Pemilik modal merupakan kelompok penguasa yang memiliki kapasitas simbolik untuk mengontrol sesuatu yang ada dibawahnya, seperti halnya negara pertama. Memiliki kekuasaan, atau hidup di negara yang memiliki kekuasaan akan memberikan suatu kemudahan akses hidup masyarakatnya, seperti akses perjalanan misalnya. Masyarakat yang hidup di negara maju cenderung memiliki akses istimewa dalam melakukan perjalanan ke luar negeri, selain faktor ekonomi, faktor kemudahan dalam hal perijinan juga menjadi penunjang lainnya. Perbandingan kelompok pemilik modal yang mampu berpetualang ke luar negeri dan yang tidak memiliki modal sangatlah kontras. Seperti halnya perbandingan antara pemegang paspor negara ketiga dengan negara pertama, bagi pemegang paspor negara ketiga tentu tidak bisa memiliki kemudahan akses seperti yang dimiliki pemegang paspor negara pertama. Hal inilah yang juga dialami kau, sebagai seorang yang lahir dari keluarga biasa dan hidup di negara berkembang, luar negeri menjadi sesuatu yang istimewa dan sulit dijangkau. Dalam hal ini diketahui negara maju atau luar negeri menjadi citra ideal dan dihasrati oleh subjek untuk mendapat pengakuan dari Liyan.

"Bersama orang tuamu, kau menyepakati dua pilihan: Hubungan Internasional dan Sastra Inggris Universitas Indonesia.... Pada saat itu kau bercita-cita jadi diplomat agar bisa jalan-jalan ke luar negeri. Ayah mendukungmu masuk Hubungan
DOI 10.22146 /poetika.56469

ISSN 2338-5383 (print) ; 2503-4642 (online)

Internasional karena namanya kedengaran hebat. Internasional: mendunia, tidak kampungan." (Paramaditha, 2017:14-15).

Dalam kehidupan tokoh kau, pengetahuan mengenai luar negeri telah melekat pada dirinya. Penanda-penanda seperti 'internasional', 'Inggris' 'jalan-jalan ke luar negeri', merupakan metafora dari masyarakat negara pertama. Segala hal yang berhubungan dengan negara pertama selalu saja menjadi sorotan di mata negara ketiga. Negara pertama selalu dipandang sebagai puncak pencapaian masyarakat, citra ideal yang diinginkan oleh masyarakat negara ketiga. Agar manusia bisa mendapat keutuhan dirinya, ia menginginkan pengakuan atas negara pertama. Masyarakat negara pertama adalah metafora akan sosok ideal. Liyan yang simbolik yang mencitrakan ego ideal bagi pembentukan diri subjek. Citraan -citraan masyarakat negara pertama memberikan dorongan yang kuat pada subjek untuk menghasrati apa yang dihasrati oleh Liyan. Hasrat tokoh kau bisa saja hasrat orang lain, dan bisa juga hasrat pengarang. Secara metonimia hasrat tokoh kau menggantikan hasrat pengarang. Dalam hal ini Intan sebagai masyarakat negara ketiga (berkembang) tidak bisa memiliki akses yang sama seperti halnya masyarakat negara maju, hal tersebut menjadikan Intan sebagai subjek yang berkekurangan.

Menurut Lacan, manusia selalu berada dalam kondisi kekurangan (lack) dan hanya hasrat yang mampu memenuhi kekurangan itu. Sebagai subjek yang berada dalam kondisi berkekurangan kau berhasrat mencari kepenuhan diri dengan bercita-cita menjadi seorang diplomat agar dapat bepergian ke luar negeri. Keinginan masuk jurusan Hubungan Internasional Universitas Indonesia (UI) menjadi sesuatu jalan yang digunakan untuk mecapai 
keinginannya berpetualang ke luar negeri. Akan tetapi kegagalannya masuk UI menjadikan dirinya berada dalam kondisi yang semakin berkekurangan. Seperti halnya yang dikatakan Lacan, bahwa meskipun subjek berhasrat mencari pemenuhan dirinya akan tetapi kekurangan dalam makna eksistensial itu tidak akan pernah terpenuhi.

Hasrat tokoh kau mewakili hasrat Intan sebagai pengarang yang juga sekaligus hasrat kebanyakan orang. Keinginan untuk menjadi yang diakui melalui penanda "hebat", "cerdas", "dibanggakan", adalah metafora dari manusia sempurna yang memiliki keberhasilan dan diakui oleh orang lain. Hasrat Intan sekaligus hasrat orang lain (pembaca) diinternalisasikan ke dalam hasrat tokoh kau yang menginginkan kesempurnaan hidup. Akan tetapi kegagalan tokoh kau dalam mencapai kesempurnaan juga merupakan metafora dari kegagalan Intan dalam mencapai kesempurnaan atau keutuhan diri.

\section{Hasrat atas “Identitas” Masyarakat Negara Pertama}

Kekurangan yang dialami tokoh kau membawanya pada pencarian kepenuhan dari yang lain, untuk bisa mencapai keinginannya. Kau kemudian melakukan persekutuan dengan iblis untuk bisa memenuhi keinginannya berpetualang ke luar negeri. Kau menjadikan iblis sebagai kekasih dan memintanya untuk memberikan sebuah tiket perjalanan tanpa pulang.

Seperti halnya Intan, sebagai seorang Warga Negara Indonesia yang lebih dari satu dekade berpindah kota dan negara, ia juga menghadirkan tokoh kau dalam novelnya sebagai seorang diaspora Indonesia yang tinggal di Amerika dan melakukan perjalanan ke negara dan kota di Eropa. Sebagai pemegang visa Indonesia, yang merupakan negara ketiga (berkembang), tentu tidak bisa memiliki akses yang sama dengan pemilik paspor Amerika sebagai negara pertama. Hal inilah yang menjadi salah satu faktor tokoh kau mengalami suatu bentuk kekurangan (lack). Kekurangan inilah yang membawanya pada hasrat mencapai kesempurnaan dengan mendapatkan identitas baru sebagai warga negara pertama seperti yang terlihat dalam kutipan berikut.
"Kau merogoh-rogoh tasmu untuk mencari paspor. Kau temukan buku kecil berwarna hijau: masih paspor Indonesia. Sial. Kenapa Iblis tak sekalian saja menghadiahimu kewarganegaraan baru? Visa Schengen menempel di salah satu halaman paspor itu, dikeluarkan oleh Konsultat Jerman di New York" (Paramaditha, 2017:10).
"Ia mengangguk-angguk, lalu bertanya tentang asalmu.
"Indonesia, setidaknya begitu yang tertulis di paspor." Jawabanmu mungkin terdengar sarkastis. Kau memang masih sedikit dongkol pada si Iblis. Status "exchange visitor" itu, apa maksudnya? Ia tertawa. Kau tak terdengar bangga menyebut negeri asalmu, komentarnya (Paramaditha, 2017:47).

Kekurangan dalam diri kau membawanya pada hasrat untuk mecapai kesempurnaan. Penanda utama muncul dari dorongan untuk menguasai diri serta mendapatkan identitas agar seseorang dapat mengenali dirinya dan dikenali orang lain. Penanda 'kewarganegaraan baru' merupakan metonimi dari Identitas warga negara dunia pertama, yang artinya subjek dapat tinggal di Amerika tanpa batas waktu yang ditentukan, juga kemudahan akses kunjungan ke negara lain. Dengan mendapatkan identitas baru sebagai warga negara pertama maka kau akan merasa utuh, sempurna, serta diakui. Namun penanda 'Indonesia' dan 'exchange visitor' merupakan metafora dari 
identitas warga negara ketiga, kau tidak bisa melepaskan diri dari identitas aslinya melalui penanda yang dimilikinya, sehingga hal ini menimbulkan rasa kurang dalam diri kau dan terus berhasrat untuk memiliki penanda yang membawa dirinya pada kesempurnaan.

Untuk bisa mencapai keinginannya tersebut, kau akhirnya memutuskan menikah dengan seorang warga asli negara pertama yaitu Amerika bernama Bob.

"Kau tak ingin sibuk berpikir soal siapa mencuil keuntungan dari siapa, apakah Bob yang memacarimu karena ia penggila perempuan Asia, atau apakah kau yang memburu Green Card dan dengan sukarela masuk ke dalam kosmologi kulit putih kelas menengah serba nyaman, nyaris steril." (Paramaditha, 2017:250).

Penanda "Green Card" merupakan metonimi dari warga negara pertama. Dengan memiliki Green Card atau United States Permanen Residence kau dapat tinggal secara permanen serta bekerja secara komersil dan legal di Amerika Serikat hingga akhirnya bisa berganti status menjadi warga negara Amerika.

Kau menginginka Green Card dengan menikahi Bob agar mendapatkan rasa kepenuhan diri. Tapi yang terjadi adalah kau hanya mendapatkan sebuah pernikahan yang tidak legal secara hukum seperti yang terlihat dalam kutipan berikut.

"Tapi ada sesuatu yang mengganjal. Setelah pernikahan dan acara makan bersama yang sederhana namun tetap merepotkan itu, ternyata kau dan Bob masih harus pergi ke administrasi kota untuk mengurus suratsurat. Kau masih harus membuat pernikahanmu legal. Dengan kata lain, kau harus berhubungan dengan negara.

"Jadi ini semua belum sah." Kau merasa gusar dan langsung melabrak Bob. Konyol betul. Kawin sama bule kok ujung-ujungnya nikah siri." (Paramaditha, 2017:292).

Penanda 'pernikahan siri' dan 'belum sah' 'merupakan metafora dari kegagalan menjadi warga negara pertama. Kondisi tersebut diperparah ketika Bob menghilang dan tidak pernah kembali lagi setelah mereka merencanakan bulan madu ke Los Angeles, yang artinya kau tidak akan pernah mendapatkan Green Card, dengan demikian keinginan menjadi warga negara pertama tidak akan pernah terpenuhi.

Keinginan untuk menjadi warga negara pertama adalah keinginan untuk mendapatkan akses yang sama dengan warga negara pertama, penanda 'akses yang sama' merupakan metafora dari keadilan. Hasrat akan keadilan adalah hasrat akan kesempurnaan, akan tetapi kesempurnaan tidak akan pernah bisa dicapai sebab kesempurnaan hanya terdapat pada fase the Real atau tatanan real, di mana tidak ada kekurangan di dalamnya, yang ada hanyalah kepenuhan diri yang sempurna. Hasrat diatur oleh sebuah sistem linguistik atau tatanan simbolik. Dalam hal ini manusia tidak akan pernah bisa melepaskan diri dari yang simbolik ia akan selalu berada pada tatanan simbolik.

\section{Hasrat Menjadi Penulis}

Melalui identifikasi hasrat Intan pada tokoh karyanya, diketahui bahwa Intan sebagai subjek berkekurangan mengarahkan dirinya menuju hasrat untuk memperoleh keutuhan diri. Hasrat untuk menjadi merupakan sesuatu yang eksternal dari diri agar dapat memberikan suatu kepuasan karena adanya pengakuan eksistensi berupa cinta kasih dari yang lain. Untuk dapat mengetahui hasrat menjadi Intan, perlu diketahui citra ideal yang ditransformasikan Intan ke dalam dirinya.

Intan kecil adalah seorang yang terbiasa membaca kasrya-karya sastra dari pengarang hebat dan terkenal seperti Grimm, H. C. Andersen dan Agatha Cristie, Intan lebih menyukai 
cerita-cerita yang berkisah tentang dongengdongen atau kisah misteri yang dikenal dengan karya sastra gotik. Kegemarannya membaca karya-karya penulis terkenal bermula dari ibunya yang memperkenalkan karya-karya penulis besar kepadanya, sejak kecil ibunya selalu memberikan buku bacaan berkualitas dan kemudian membiasakan Intan untuk berdiskusi dengannya terkait buku yang sudah mereka baca (Faiq, 2017:17). Dalam hal ini terlihat bagaimana ibu menjadi cermin pertama Intan dalam identifikasi diri sebagai citra ideal. Diketahui citra ideal Intan adalah ibunya yang diketahui melalui penanda "terbiasa memberikan buku bacaan berkualiatas" dan "berdiskusi" menunjukkan bahwa ibunya adalah seorang perempuan yang pintar. Kegemarannya membaca berlanjut hingga dewasa. Intan yang kemudian mengambil jurusan Sastra Inggris di Universitas Indonesia membuat dirinya semakin tertarik dengan bacaan-bacaan yang lebih berat. Intan banyak membaca karyakarya penulis besar seperti karya Toeti Heraty, Margareth Atwood, Angela Carter dll. Proses pembelajaran dan inspirasi yang ia dapatkan dari para sastrawan dunia khususnya barat inilah yang memunculkan hasrat dalam dirinya. Tokoh-tokoh tersebut membawa identitas tertentu untuk dihasrati sekaligus memunculkan hasrat menjadi pada diri Intan. citraan ideal pada tokoh-tokoh tersebut meletakkan penanda seperti "terkenal", "karya besar", "diakui", dan sebagainya yang merujuk pada identitas seorang penulis hebat. Penanda-penanda tersebut merupakan metonimi dari seorang sastrawan yang dikagumi oleh masyarakat luas termasuk Intan, hal itulah yang memunculkan hasrat Intan untuk menjadi penulis.
Penanda yang merujuk pada hasrat Intan untuk menjadi penulis juga ia manifestasikan ke dalam karyanya melalui penanda-penanda tertentu seperti yang terlihat dalam kutipan berikut.

"Kau tak ingin terlalu jujur dengan mengatakan bahwa sebelum bekerja di kafe kau adalah seorang pengangguran.

"aku sedang menulis buku."

"Mungkin suatu saat kau jadi orang Indonesia pertama yang masuk daftar 100 buku terpilih Nes York Times."

(Paramaditha, 2017:282-283).

Penanda 'menulis buku', 'penulis perempuan Indonesia', 'orang Indonesia pertama yang masuk daftar 100 buku terpilih New York Times.' Merupakan metafora dari penulis hebat, terkenal, diakui. Dalam hal ini, diketahui Intan berkeinginan menjadi penulis hebat yang diakui oleh negara pertama. Keinginan menjadi penulis adalah wujud dari hasratnya menjadi objek cinta. Dengan mendapatkan pengakuan sebagai seorang penulis hebat maka ia akan mendapatkan pengakuan dan dikagumi oleh masyarakat terutama masyarakat dunia pertama. Dengan demikian, tindakan Intan dalam menulis merupakan bentuk dari hasrat narsistik di mana Intan berhasrat untuk menjadi objek cinta, kekaguman dan pengakuan dari masyarakat agar subjek merasa dicintai oleh Liyan yang Simbolik.

\section{Hasrat Memiliki Keutuh (Kesempurnaan): Kebebasan dan Keadilan bagi Warga Negara Ketiga}

Intan Paramaditha sebagai subjek yang berkekurangan terus menerus mencari objek $a$ sebagai pemenuhan akan kekurangan dirinya. Kekurangan yang dirasakan Intan bermula ketika ia mulai bepergian dan tinggal di negara pertama. Sebagai Warga Negara Indonesia (negara 
ketiga) yang telah lebih dari satu dekade berpindah kota dan negara membuat Intan banyak menyerap berbagai wacana sosial. Ia juga harus berasimilasi dengan lingkungan serta budaya baru di negara-negara pertama yang memiliki perbedaan dengan Indonesia mengenai kondisi budaya (cara berpikir, adat istiadat), kesejahteraan, serta hukum yang berlaku. Perbandingan tersebut dimunculkan oleh Intan dalam novel Gentayangan dalam kutipan berikut.

"Kau tahu kenapa fiksi sains menjamur di negara dunia pertama? Mereka menguasai teknologi. Mereka membayangkan perjalanan ke galaksi lain karena mereka bisa. Saat terminal ini dibangun dengan gagasan luar angkasa, negara dunia ketiga sibuk sendiri. Ada istilah untuk itu. Kalau tak salah dekolonisasi." (Paramaditha, 2017:36).

Dalam kutipan tersebut, penanda 'dekolonisasi' merupakan metonimi dari kemerdekaan warga negara ketiga. Hal tersebut memperlihatkan bahwa ketika masyarakat negara ketiga masih disibukkan dengan urusan kemerdekaan bangsanya, masyarakat negara pertama sudah jauh melampaui mereka sehingga dapat memikirkan kemajuan teknologi dan ilmu pengetahuan sebab mereka tidak dipusingkan dengan urusan kemerdekaan, mereka adalah bangsa yang telah bebas, merdeka, dan sejahtera.

Selalu ada kesenjangan sosial antara negara pertama dengan negara ketiga. Melalui novel Gentayangan, Intan menghadirkan tokoh kau yang bersekutu dengan Iblis yang mampu bepergian dan tinggal secara bebas ke negara-negara pertama. Penanda 'Iblis' dalam hal ini sebagai metafora kebebasan, Ia bebas kemana saja, sebab Iblis tidak bernegara, tidak berumah, dan tidak memerlukan surat-surat untuk tinggal dan bepergian. Penan- da 'gentayangan' berarti kebebasan bepergian tanpa terikat hukum dan aturan. Dalam hal ini, Intan sebagai subjek yang berkekurangan mencari pemenuhan hasratnya melalui karyakaryanya sebagai bentuk akan kebebasan yang ia inginkan sehingga ia dapat kembali utuh, sempurna, tanpa kehilangan dan kekurangan. Pemberian judul Gentayangan merupakan metafora atas kebebasan yang ia inginkan.

\section{Hasrat sebagai Pembentuk Subjek Maskulin}

Lacan mengatakan seseorang akan menjadi subjek ketika ia memiliki hasrat akan sesuatu. Hasrat Intan Paramaditha akan kebebasan dan keadilan bagi warga negara ketiga juga menjadi hasrat seluruh warga negara ketiga, khususnya bagi mereka yang tinggal di negara pertama. Sebagai warga negara Indonesia memaksakan dirinya untuk mematuhi hukum-hukum tentang batas negara yang berlaku di negara pertama. Perbedaan perlakuan mengenai akses perjalanan dan izin tinggal terhadap warga negara ketiga dengan warga negara pertama membatasi ruang gerak dan kebebasan Intan sebagai warga negara Indonesia yang tinggal di Amerika. Sebagai seorang akademisi, Intan perlu melakukan berbagai kunjungan diberbagai kota maupun negara untuk keperluan penelitiannya. Kesulitan yang juga dialami oleh seluruh warga negara ketiga yang tinggal di negara pertama, terutama bagi warga negara peperangan yang berharap perlindungan dan rasa aman di negara pertama. Dalam hal ini kebebasan dan keadilan menjadi objek hasrat (falus) yang diinginkan Intan dan seluruh warga negara ketiga untuk mencapai rasa akan keutuhan dan kesempurnaan. Akan tetapi kebebasan dan keadilan yang diinginkan Intan terhambat dengan adanya hukum yang dalam istilah Lacan disebut Name of the Father, dimana ayah simbolik (hukum yang berlaku di 
negara pertama) hadir dan melakukan pengebirian terhadap dirinya sebagai warga negara ketiga dengan aturan mengenai hukum batas wilayah. Pengebirian juga dipahami memiliki arti yang mirip dengan keterasingan (alienation) dan keterpisahan (separation). Dalam hal ini, Intan mengalami keterasingan sebab sebagai warga negara ketiga yang memiliki hasrat akan kebebasan dan keadilan seperti halnya yang dimiliki warga negara pertama untuk mencapai keutuhan diri terhalang oleh adanya hukum yang berlaku (ayah simbolik).

Lacan mengatakan, ketika ayah simbolik melakukan pengebirian terhadap sang anak, sang anak dihadapkan dalam dua pilihan, yaitu menaati atau menolak. Dalam hal ini, keinginan Intan untuk mewujudkan hasrat akan kebebasan dan keadilan bagi warga negara ketiga ia manifestasikan ke dalam karya-karyanya, khususnya novel Gentayangan. Intan melakukan perlawanan terhadap ayah simbolik (hukum yang berlaku) melalui karyanya. Negara pertama diibaratkan sebagai penguasa yang memiliki otoritas untuk mengatur hukum di dunia. Dalam hal ini, Intan menginginkan keadilan bagi seluruh manusia, baik bagi sang pemilik modal maupun mereka yang tidak memiliki modal ataupun kekuasaan. Ia menghadirkan penandapenanda yang merujuk pada perlawanan terhadap sang pemilik modal, sang adikuasa, yaitu negara pertama. Penanda tersebut dapat dilihat dari pemilihan judul 'Gentayangan' yang dihadirkan pula anak judul 'Pilih Sendiri Petualangan Sepatu Merahmu.' Sepatu merah adalah hadiah pemberian iblis kekasih sebagai alat kau untuk berpetualang menembus batas. Penanda "Merah" pada sepatu merah adalah metafora dari perlawanan akan adanya ayah simbolik, sebab merah selalu dikaitkan dengan sesuatu yang buruk atau dijauhi. Merah memiliki arti polistis dalam sejarah Indonesia. Pada masa Orde Baru berkuasa, terjadi politik warna. Warna merah menjadi warna yang dijauhi karena identik dengan Partai Komunis Indonesia (PKI), pada masa tersebut PKI selalu dianggap sebagai kubu kiri, dianggap pemberontak, dan mendapat stigma buruk di masyarakat. Kebencian (ketakutan) pada warna merah sangat mengakar pada masa Orde Baru. Hal tersebut dimunculkan juga oleh Intan dalam novel Gentayangan ketika tokoh Kau masih SMA. Pada masa itu (tahun 90-an) budaya kakak kelas menindas adik kelas marak terjadi di sekolah, saat itu Kau masih menjadi siswa baru di sekolahnya. Suatu ketika ia melihat kejadian penindasan yang dilakukan oleh kakak kelasnya terhadap teman seangkatan Kau yang dianggap terlalu cantik dan mencolok di kalangan siswa lain. Kakak kelas yang merasa tersaingi menindas dan memperolok mereka dengan menyebut mereka sebagai PKI seperti yang terlihat pada ketipan berikut.

"Perempuan berbaju merah dengan silet di tangan bisa melakukan apa saja.

Adegan sadis selalu membuatmu menutup mata di kelas empat, lima, enam. Setelah itu kau tak mau lagi menonton film Pengkhianatan G30S/PKI, tapi wajah-wajah kesakitan selalu ada di sana, pada batu dikutuk membeku. Relief ingatan bertekuk-tekuk. Gothic.

Ingatan tentang PKI dan Gerwani, entah mengapa, selalu terhubung dengan sebuah peristiwa di sekolah. (Paramaditha, 2017:120).

"Gak usah cari perhatian!"

“Mau jadi PKI lo ya?" tambah yang lain.

"Mau jadi perek, lo? Kelakuan udah kayak Gerwani!"

"Iyalah, Gerwani. Mereka 'kan lesbi." (Paramaditha, 2017:122). 
Pada masa Orde Baru, anak sekolah mulai dari SD kelas 4 hingga SMA diwajibkan pemerintah untuk menonton film Pengkhianatan G30S/PKI setiap tahunnya pada tanggal 30 September. Bagi anak di bawah usia film berisi kekerasan seperti itu akan membawa trauma bahkan secara tidak langsung dapat mempengaruhi karakter dan kepribadian anak. Seperti halnya yang terjadi pada tokoh $\mathrm{Kau}$, terbiasa menyaksikan film Pengkhianatan G30S/PKI membuatnya hanya menonton tindakan penindasan yang dilakukan kakak kelas terhadap temannya. Dalam hal ini Intan seolah ingin mengatakan bahwa masyarakat Indonesia terbiasa dengan budaya menindas, sebab sejak kecil anak-anak dipaksa untuk melihat adeganadegan penindasan dan kekejaman di film Pengkhianatan G30S/PKI. Penanda 'merah' pada perempuan berbaju merah merupakan metafora dari gerwani yang dianggap sebagai perempuan pemberontak. Sama halnya dengan PKI, masyarakat yang selalu diwajibkan menonton film Pengkhianatan G30S/PKI telah secara tidak langsung menanamkan bahwa PKI adalah pemberontak, sebagai contoh perbuatan melawan pemerintah. Maka stigma negatif terhadap PKI sering kali dijadikan sebagai julukan bagi seseorang yang berani melawan mereka yang merasa berkuasa.

Penanda 'PKI' dan 'Gerwani' dalam kutipan tersebut merupakan metafora dari pembangkang, julukan PKI digunakan bagi mereka yang dianggap sebagai pembangkang terhadap pihak yang merasa memiliki kekuasaan. Penanda tersebut pada masa itu selalu dikaitkan dengan warna merah, sebagai simbol para pengkhianat. Penanda 'merah' juga biasa dikaitkan dengan setan/ iblis, sebagai warja kejahatan, sisi kiri seperti halnya Iblis yang juga ia hadirkan dalam novelnya tersebut. Sosok Iblis adalah diibaratkan sebagai makhluk tak berumah, tak bernegara, dan tak memerlukan surat-surat sehingga ia tidak juga terikat dengan hukum apapun di dunia sehingga ia memiliki kebebasan yang juga diinginkan oleh Intan. Dalam hal ini Intan Paramaditha sebagai subjek mengalami kastrasi/ pengebirian akibat adanya hukum ayah, subjek yang mengalami pengebirian oleh ayah simbolik tidak hanya terjadi pada laki-laki namun juga perempuan. Subjek yang demikian yang dimaksud dalam pandangan Lacanian adalah subjek maskulin. Intan sebagai subjek yang mengalami pengebirian oleh ayah simbolik (hukum) melakukan perlawanan terhadapnya melalui tindakannya menulis novel yang berjudul Gentayangan (Pilih Sendiri Petualangan Sepatu Merahmu).

\section{Simpulan}

Merujuk psikoanalisis Lacan, dapat dikatakan bahwa novel Gentayangan merupakan manifestasi hasrat dan kekurangan dalam diri Intan Paramaditha sebagai pengarang. Dalam penelitian terhadap novel Gentayangan ini peneliti menemukan Intan Paramaditha sebagai subjek yang berkekurangan. Melalui kekurangan dalam diri Intan inilah yang memunculkan hasrat pada dirinya yang dimanifestasikan ke dalam karyanya. Hasrat Intan Paramaditha dalam novel Gentayangan ditemukan menggunakan metode psikoanalisis Lacan yaitu melalui mekanisme metafora dan metonimia. Dengan menggunakan metode psikoanalisis Lacan dan mekanismenya, maka penelitian ini menyimpulkan beberapa hal. Pertama, hasrat Intan Paramaditha untuk menjadi (narsistik) penulis merupakan hasil identifikasi dirinya terhadap ibunya dan tokoh- 
tokoh penulis besar.

Kedua, hasrat memiliki (anaklitik) pada novel Gentayangan ditemukan bahwa Intan sebagai subjek yang berkekurangan berusaha mencari keutuhan melalui objek $a$, yang dalam hal ini Intan ingin memiliki keutuhan dan kesempurnaan melalui kebebasan dan keadilan bagi warga negara ketiga mengenai akses berkunjung ke negara lain.

Kebebasan dan keadilan menjadi objek hasrat (falus) yang diinginkan Intan dan seluruh warga negara ketiga untuk mencapai rasa akan keutuhan dan kesempurnaan. Akan tetapi kebebasan dan keadilan yang diinginkan Intan terhambat dengan adanya hukum Name of the Father. Dalam hal ini Intan Paramaditha sebagai subjek yang teralienasi akibat adanya hukum ayah melakukan perlawanan terhadap ayah simbolik (hukum batas wilayah) melalui novelnya yang berjudul Gentayangan. Maka dengan demikian, Intan Paramaditha adalah subjek maskulin yang mengalami pengebirian akibat adanya ayah simbolik dan melakukan perlawanan terhadapnya.

\section{Daftar Pustaka}

Bracher, M. 2009. Jacques Lacan, Diskursus, dan Perubahan Sosial: Pengantar Kritik Budaya Psikoanalisis. Yogyakarta: Jalasutra.

Faiq, M. H. 2017. "Kadang Perlu Ditampar". Dalam Kompas, 24 Desember 2017. Jakarta.
Faruk. 2017. Metode Penelitian Sastra. Yogyakarta: Pustaka Pelajar.

Hiasa, Fina. 2016. "Desire for the Real in Novel Akar by Dee (Kerinduan pada yang Riil dalam Novel Akar Karya Dee)". Dalam Poetika, No. 2, Vol. IV, Desember, Hal. 66.

Kolenc, Bara. 2017. "The Paradodoxes of The Limping Cause in Kierkegaard, Hegel and Lacan". Dalam Journal of the Circle for Lacanian Ideology, No. 1, Vol. XI, Hal. 90108.

Lukman, Lisa. 2011. Proses Pembentukan Subjek Antropologi Filosofis Jacques Lacan. Yogyakarta: Kanisius.

Paramaditha, Intan. 2017. About. Diakses pada 15 Januari 2019, dari Intanparamaditha.org website: http:// intanparamaditha.org/about/

Paramaditha, Intan. 2017. Gentayangan Pilih Sendiri Petualangan Sepatu Merahmu. Jakarta: Gramedia Pustaka Utama.

Rengganis, Ririe. 2015. "Bahasa sebagai Pembentuk Subjek pada "4in1 Djenar" Karya Djenar Maesa Ayu: Kajian Psikoanalisis Lacanian". Disertasi Program Studi Sastra. Yogyakarta: Universitas Gadjah Mada.

Manik, Ricky A. 2016. "Hasrat Nano Riantiarno dalam Cermin Cinta: Kajian Psikoanalisis Lacanian". Dalam Poetika, No. 2, Vol. IV, Desember, Hal. 74-84. Yogyakarta: Universitas Gadjah Mada.

Watson, Cate. 2013. "Identification and desire : Lacan and Althusser versus Deleuze and Guattari? A short note with an intercession from Slavoj Žižek". Dalam International Journal of Zizek Studies. United Kingdom. No. 2, Vol. VII, Hal. 1-16. 